Vol. 5, No. 2, 2019

УДК 327:28-768(4)

https://doi.org/10.23939/shv2019.02.008

\title{
THE CONSPIRACY CONCEPTION OF WORLD JIHAD AS AN INSTRUMENT FOR THE ISLAMIZATION OF EUROPE
}

\author{
Olha Ivasechko \\ Lviv Polytechnic National University \\ ORCID ID 0000-0003-2141-3309 \\ ivasechko.2011@ukr.net \\ Yaryna Turchyn \\ Lviv Polytechnic National University \\ Researcher ID R-1932-2017 \\ Author ID: 57192268948 \\ turchynj@ukr.net
}

(стаття надійшла до редколегї - 22.09.2019 р., прийнята до друку-21.10.2019 р.)

(C) Івасечко О., Турчин Я., 2019 p.

The article reveals the essence of the conspiracy concept of world jihad as an instrument for the Islamization of Europe and explores its influence on public opinion in Western European countries.

The assessment of the existing and potential risks of conspiratorial thinking spread in Western European countries accomplished by The International Center for The Study of Radicalization and Political Violence (ICSR), as well as the Think Tank Pew Research Center experts' forecasts as an attempt to refute the conspiracy concept about the inevitable world jihad implementation through demographic transformation have analyzed. It has been found that, despite the increasing proportion of Muslims in the European population, there are no objective reasons for claiming the inevitability of world jihad.

It has been concluded that the «Islamophobia» virus, like other conspiracy concepts based on stereotypical notions about certain peoples, is not a new phenomenon. However, the conspiracy theories about the transformation of the European region into the so-called «Eurabia» have become especially relevant in the context of recent intensification of migration flows to European countries. Proceeding from the latest news about different conspiratorial statements of Western European political leaders, the disregard of the outbreaks of the «conspiracy thinking epidemic» and the use of Islamophobic conspiracy concepts to misinform people will necessitate declaring the region a «quarantine zone».

Key words: conspiracy theories, world jihad, Islamization, Eurabia, Western Europe, Islamophobia, migration.

\section{КОНСПІРОЛОГІЧНА КОНЦЕПЦІЯ СВІТОВОГО ДЖИХАДУ ЯК ІНСТРУМЕНТ ІСЛАМІЗАЦІЇ СВРОПИ}

\author{
Ольга Івасечко \\ Національний університет «Львівська політехніка» \\ ORCID ID 0000-0003-2141-3309 \\ ivasechko.2011@ukr.net \\ Ярина Турчин \\ Національний університет «Львівська політехніка» \\ Researcher ID R-1932-2017 \\ Author ID: 57192268948 \\ turchynj@ukr.net
}

У статті розкрито суть конспірологічної концепції світового джихаду як інструменту ісламізації Свропи та досліджено їі вплив на громадську думку в західносвропейських країнах. 
Проаналізовано оцінку наявних та потенційних ризиків поширення конспіративізму в країнах Західної Європи, здійснену Міжнародним центром із вивчення екстремізму та політичної ненависті, а також розглянуто прогнози експертів із дослідницького центру Think Tank Pew Research Center як спробу розвіяти конспірологічний концепт про неминуче встановлення світового джихаду шляхом демографічних трансформацій. 3'ясовано, що, незважаючи на збільшення частки мусульман серед європейського населення, об'сктивних підстав для ствердження про неминучість становлення світового джихаду немас.

Зроблено висновок про те, що вірус «ісламофобії», як і інші теорії змови, засновані на стереотипному уявленні про певні народи, не с новим явищем, однак останнім часом конспірологічний концепт про перетворення європейського регіону на «Єврабію» став особливо актуальним в умовах інтенсифікації міграційних потоків до країн Свропи.

У світлі останніх новин про заяви конспіративного характеру західносвропейських державних лідерів, за умови ігнорування проблеми спалахів «епідемії» конспіративного мислення та використання ісламофобних теорій змови $з$ метою дезінформування та спотворення уявлення про дійсний стан справ, в Західній Європі доведеться оголосити «карантин».

Ключові слова: конспірологічні теорії, світовий джихад, ісламізація, Єврабія, Західна Європа, ісламофобія, міграція

In the context of the dynamics of modern realities the destructive effect of conspiracy concepts on the individual's consciousness is often underestimated due to the tendency toward stereotypical interpretation of conspiracy theories as manifestations of psychopathology. In the 21 st century, the interest of the scientific community in this phenomenon has grown significantly due to the transformation of modern conspiracy theories into «weapons of mass destruction», which is turning more and more people into puppets by manipulating their thoughts. The «virus of conspiracy thinking» is causing an epidemic of various «social diseases», such as terrorism, radicalization, racism, health problems, and many others.

The problem of using conspiracy concepts as levers of influence on public opinion is particularly relevant in Western European countries, in which the conspiratorial context of reality perception is followed in almost all spheres of public life. Moreover, the use of conspiracy theories by international actors as an instrument to achieve their own latent interests through misinformation and propaganda negatively affects the flow of cognitive processes and distorts the idea of reality generating many alternative variants of reality description. However, the emergence and popularization of conspiracy theories also serve as an indicator of the weaknesses in a society that can help prevent relapses in the future if prompt actions to eliminate the conspiratorial manifestations at early stages are taken.

The purpose of the article is to reveal the essence of the conspiracy concept of world jihad as an instrument for the Islamization of Europe and to explore its influence on public opinion in Western European countries.

Today, one can witness a significant increase in the researchers' interest in the study of the conspiracy theories popularization problem in Western Europe and the use of conspiracy theories by politicians in the fight against each other. The interest of scientists is mainly conditioned by the intensification of migration flows to the Western European region that serves as a material for producing conspiracy theories, in particular, the theory of Europe Islamization. The researchers from the International Centre for The Study of Radicalization and Political Violence (ICSR), A. Meleagrou-Hitchens and B. Hans [Meleagrou-Hitchens \& Hans 2013], focus on the problem of the so-called «defense leagues» emergence within the European movement against jihad. They also emphasize the global scale and dire consequences of the leagues' activities, promoted by governments and influential organizations and individuals around the world. Hafez, analyzing the statements of European politicians, demonstrates examples of using the concept of Islamization as a tool to manipulate public opinion and to present Muslims as a world antagonist [Hafez 2018]. Nemirovskyi based on the results of the research conducted by the Think Tank Pew Research Center, concludes that despite the rapid increase in the proportion of Muslims in Europe, the transformation of the region into Eurabia remains only a myth being actively spread by anti-jihadists [Nemirovskyi 2017]. In general, it is worth noting that despite the considerable achievements of scientists in the field of research on conspiracy theories, this phenomenon still leaves a blank space, filling which is one of the priority tasks on the agenda.

The era of information technology, which has set a completely new pace of social life, both locally and globally, has conducted to the canalization of the «paranoid thinking epidemic» spread. In today's world, the consciousness of the individual has become much more vulnerable to the «conspiracy virus», and the latest means of data dissemination has created the most favorable environment for its existence. Nowadays, there are not many people who have immunity to the virus, the meaning of which cannot always be equated with 
common sense since information is often perceived at the subconscious level.

According to Uscinski, every person, being aware of it or not, believes in at least one conspiracy theory. Thus, it can be argued that the image of the modern adherent of a particular conspiracy concept is far from the stereotypical notion of a «fanatical conspirator who, being trapped in his or her own bunker, is awaiting the end of the world» [Brotherton, French \& Pickering 2013; Uscinski 2017]. In turn, psychologist Chris French asserts that according to official demographic data, everyone, regardless of national, religious, racial, political views, social class, gender, or age, is prone to believe in conspiracy theories [Tilley 2019; Brotherton, French \& Pickering 2013].

Power has always been one of the «immortalized images of the public enemy». People are used to blaming representatives of the ruling elite for all the existing problems, from the state crisis to their own financial difficulties, without thinking about whether a particular negative phenomenon was caused by the actions or inaction of the state leaders. However, it is extremely important that the political reality of the 21 st century is characterized by the exacerbation of the problem of using conspiracy theories as a weapon by international actors against each other. The use of conspiracy theories as propaganda and misinformation poses a real threat of the spread of hatred and violence and the promotion of hostility, which entails the probability of conflict emergence between representatives of different states.

The ideas about Muslims' intentions to take the highest position in the hierarchy of the peoples have always been widely popular among adherents of conspiratorial thinking. The implementation of the «sinister plan» was supposed to start in Europe through its gradual Islamization. This conspiracy concept has become especially relevant in the current situation in the region, namely as an explanation of the phenomenon of intensification of migration flows to European countries.

The conspiracy concept about Muslims' desire to dominate other peoples is not a new phenomenon. Yet, the rise of its popularity started in 2005 with the publication of the book called Eurabia written by someone under the pseudonym Bat Ye'or, whose main idea was based on the theory of inevitable Islamization of Europe. The author states that the start-up process was activated in 1973 during the OPEC oil embargo when the Euro-Arab Dialogue (EAD) program was created to intensify cooperation between the European Economic Community and the Arab world. However, according to Ye'or, it was actually used to camouflage the true intentions of the conspirators. In fact, at the time, a secret agreement was concluded that foresaw the annihilation of
Israel and the cultural conquest of Europe by Muslims, as well as European governmental non-interference because of the desire to become part of the Arab oil economy and the fear of the threat of terrorism. This is allegedly holding Europe's political elite from radical action on the mass migration flows of Muslims to the region. In support of her claims, the writer refers to the history of Islam, namely to the so-called concept of dhimma, and calls modern Muslims the «torchbearers in the tradition of anti-Semitism and imperialism», the roots of which date back to the origins of the Islamic religion. The concept of dhimma depicts a future in which «nonMuslims live in fear because of the oppression by the Ottoman Empire». Ye'or also draws a parallel between what is described and the present, calling European governments' cowards who capitulate to the Islamic threat [Meleagrou-Hitchens \& Hans 2013: 45].

In this way, the book "Eurabia» has become a guide for the adherents of the conspiracy theories on Islamization of Europe and has given impetus to the formation of many Islamophobic groups around the world.

The International Centre for the Study of Radicalization and Political Violence (ICSR) draws attention to the existence of the so-called European movement against jihad, whose representatives are identified as pan-European far-right fighters against Muslim influence and Islam. Since the inception of this international alliance in the late 2000s, there has been a tendency toward the formation of its more sophisticated operational structure. Proponents of the movement declare Muslims an internal enemy and a threat to European culture. Their ideology derives from the existing stereotypical image of terrorists seeking to dominate Western civilization. They are also adherents of the conspiracy theory about Europe Islamization through Shariah implementation which presupposes that all European Muslims are members of a secret arrangement and, in fact, have been deported to the region as invaders. Almost all of the actions of Muslim migrants are considered through such an ideological prism, which allows Islamophobes to generate more and more conspiratorial rumors [Meleagrou-Hitchens \& Hans 2013:3].

Experts from the ICSR highlight the following serious problems with the movement's activities:

1. The narratives of the anti-Muslim alliance members, based on paranoid aspirations to conspiracy theories, can be a source of inspiration for violent terrorist attacks, similar to those committed by Anders Breivik, a descendant of the ideological environment of jihad movement, who has killed 77 innocent people in Norway [Meleagrou-Hitchens \& Hans 2013:4]. 
2. The Alliance can serve as an incubator, a protective shield, and a mentor for adherents of traditional forms of far-right xenophobia and extremism [Meleagrou-Hitchens \& Hans 2013:4].

3. The amorphous nature of the movement and the ability of its members to direct public concern about immigration, economy, terrorism, and religion into the required channel increases the likelihood of confrontation and endangers the social structure of Europe [Meleagrou-Hitchens \& Hans 2013: 4].

Since its inception, the Jihad movement has gained popularity among a number of political figures in the United States. Popular American Islamophobic activists, Pamella Heller and Robert Spencer, praise the emergence of such an alliance and are helping to form similar groups across Europe. Under their leadership, a large-scale campaign is being promoted through networking and demonstrations, the purpose of which is to withstand the Muslim invasion, as well as to increase the number of the defense leagues across the European continent [Meleagrou-Hitchens \& Hans 2013:4].

The problem is compounded by the fact that instead of revealing a «true enemy» camouflaged under the guise of a «fighter against the evil», the governments of states believe in conspiracy theories and even promote their spread. For example, according to the Presidentof the Czech Republic, Milos Zeman, refugees are the «invasion agents» of the International Brotherhood of Muslims that seeks to gain control of Europe. In his view, the explosion of uncontrolled migration flows is the result of a well-thought-out plan to Islamize the European continent. The politician justifies his assumption stating that the Muslim organization does not have the resources necessary for military invasion, so it achieves its goals through demographic transformation. Although Zeman's statements are perceived as disrespect for the refugees accused of acting as puppets or conspiracy members, while being forced to leave their loved ones and flee to Europe in order to save their lives, such outbreaks of slander continue to take place [Hafez 2018].

Among those, who are involved in the conspiracy, in the view of the Islamization theory adherents, are also representatives of the European liberal elite, who refuse to resist the Muslim invasion either out of fear or because of their own benefit from the prevailing chaos. According to anti-jihadists, if European governments do not apply radical means of combating the invaders, it will lead to a civil war turning the region into ruins that will become the foundation for «a new caliphate under the strict Islamic Sharia» [Meleagrou-Hitchens \& Hans 2013: 3-5].

In light of current events, the President of France Emanuel Macron and German Chancellor Angela
Merkel, who ostensibly agreed to sell Alsace-Lorraine to Berlin, also became the victims of allegations of involvement in a secret conspiracy. The statements came from extreme right-wing French politicians in response to the bilateral Treaty on Franco-German Cooperation and Integration signed in Aachen [Understanding Conspiracy Theory 2016].

The intensification of migration flows to Europe, which allegedly threatens the public well-being of European countries, has caused a wave of discontent among the population. Representatives of the right-wing coalition in Italy also took part in «truth revealing» about the phenomenon of migration. According to them, the main culprit is France which «has never stopped Africa colonization», while the UN treaty on migration was signed in order to import tens of millions of migrants to Europe. French journalist, Natalie Nougayrède, says that «there has always been something quasi-sacred in the Franco-German reconciliation, and the fact that conspiracy theories about the sale of Alsace-Lorraine and France's involvement in mass migration have easily affected many of the Europeans really makes one ponder».

What is more, the recent unprecedented protests in France involving the so-called «yellow vests» have become the real godsend for Islamophobic conspiracy theorists. The discontent of French citizens over the rule of the current president has sparked a mass of conspiracy theories that have prompted revolutionary motives among the Muslim Brotherhood Association, which is thus bringing to life its ominous plan to seize Europe, wreaking havoc in the region. This opinion is shared by the pro-government Egyptian press and high-ranking officials from the Arab Emirates. Some media channels report that protesters included members of a Muslim organization in Morocco, Tunisia, and Algeria. Moreover, their activities are being funded by the CIA and Donald Trump [Hafez 2018].

Despite the lack of factual evidence, conspiracy theories about the Islamization of the European region continue to gain considerable popularity in Western Europe. Activists from these countries, as well as from the United Kingdom, France, Belgium, and Denmark, say that the authorities have turned away from the citizens, «leaving them at their best in the fight against the usurper». That is why it is crucially important to unite the European peoples into one powerful force capable of eradicating the Islamic evil once and for all [MeleagrouHitchens \& Hans 2013:5].

Adoption of conspiracy theories on the Islamization of Europe is another confirmation of the fact that when the situation goes beyond the established canons, society loses its ability to think analytically, 
panicking and reflexively projecting its fear on an «invisible enemy». The Think Tank Pew Research Center has made an attempt to investigate whether migrant flows to Muslim countries in Europe are part of global collusion and whether the region's conversion to Eurasia is to be expected in the near future [Nemyrovskyi 2017].

According to the study, there are three potential scenarios for increasing the number of Muslim migrants in Europe by 2050. The experts state that demographic changes towards Islamization are inevitable, even if all preventive measures, such as the prohibition of any form of legal migration, are taken at this stage. The question is, how crucial these transformations will be, and whether the European region is expected to be transformed into «Eurabia» [Nemyrovskyi 2017].

In general, the researchers identify the following potential scenarios:

- the «zero migration» scenario. According to this forecast, even with the complete absence of new migration flows, the number of Muslims in European countries will still increase by about $2.5 \%$ and by $3.8 \%$ in Germany, due to the fact that the age of already «settled» representatives of the Muslim population is 13 years less than of the locals and the birth rate is higher;

- the «average immigration» scenario. It foresees an increase of the proportion of Muslims in Europe up to $11 \%$, taking into account only those with work, tourist or student visas, while the political asylum will be suspended;

- the «high immigration» scenario. This option actually describes the current situation. If we leave everything unchanged, Muslims will make up $14 \%$ of the population of European countries and $20 \%$ of German population [Nemyrovskyi 2017].

According to Conrad Hackett, the head of the research team, the forecast is hypothetical and is cannot fully reproduce the real picture of the future, but it can be useful to the public and political representatives when considering potential options for solving the problem, as well as to demonstrate what consequences the restrictive migration policy for Muslims may cause. Moreover, the research findings can be used as counterarguments in response to statements by fanatical Islamophobes who argue that Europe will be completely transformed into territory of Muslim domination. Although the scenarios presented for a potential future are merely a «theoretical experiment», they confirm the fact that the number of Muslims in Europe is increasing, but is still very far from the critical limit; the hypothesis of full Islamization of the European region remains at the stage of conspiracy theories [Nemyrovskyi 2017].
As a result of the research it has been found that conspiracy concepts are not a consequence of modern globalization transformations of the social realities dynamics. The $21 \mathrm{st}$ century as an era of digital technology has only contributed to the transformation of existing conspiracy theories into new forms that can spread much faster thanks to the classic media and the Internet. In fact, conspiracy theories have always accompanied humanity, generating an alternative version of history by distorting the notions of certain events and creating stereotypes and prejudices.

Conspiracy theories are not just a «side effect» of social mobility, they are the ideas that emerge in the public space and require careful study and analysis of their origins, causes of the emergence, and catalysts of their dissemination in order to prevent their transformation into a powerful «weapons of mass destruction» of human consciousness. They are an important discourse through which one can see and understand the essence of the problems of a particular society.

Conspiratorial players are influential fanatical leaders, «the dark forces» of the international arena who are able to infect and manipulate the public consciousness in order to meet their own latent interests. The conspiracy theorists are the traders of ideas which, unfortunately, still find their buyers. Despite the fact that most people refer to conspiracy theories with welldefined skepticism or direct underestimation, they still remain popular and continue to make destructive changes in society.

Having analyzed the news from European political life, it is safe to say that Europe, especially the West, has created around itself a giant web made of conspiracy theories. The governments are actively using conspiracy theories against each other, which negatively affects public consciousness. Most people «automatically absorb information» without subjecting it to filtering and critical reflection, and if the allegations contained in certain conspiracy theories can also provide the «explanation» of the individual's personal problems related to low living standards, unemployment, etc., it is almost impossible to convince people in their untruthfulness.

The theory of the European region transformation into Eurabia, as a result of the implementation of the ominous plan of the Muslim Brotherhood to conquer the peoples of the world, is another proof that the existing international system has got a weak spot. The world community is unable to cope with the dynamics of modern realities due to the rapidly progressing processes of globalization. Once again the same mistakes are being made by blaming the latent antagonist, in this case, Muslims. 


\section{ЛІТЕРАТУРА}

Немировський Б. (2017). Бути чи не бути «ісламізації» Європи, або Три імміграційні сценарії для ЄС. 24 канал, 1 грудня. Отримано 3 https://24tv.ua/buti_chi_ne_buti_islamizatsiyi_yevropi_abo_tri _immigratsiyni_stsenariyi_dlya_yes_n896354

Тилли, Дж. (2019). Почему столько людей верят в теории заговора. BBCNews (Украӥна), 13 лютого. Отримано 3 https://www.bbc.com/ukrainian/ features-russian-47224739

Brotherton R., French C. \& Pickering D. (2013). Measuring belief in conspiracy theories: the generic conspiracist beliefs scale. PubMed, May 21. Отримано 3 https://www.ncbi.nlm.nih.gov/pubmed/ 23734136

Hafez , F. (2018). Another Islamophobic conspiracy theory: The Islamization of the 'yellow vests'. Fundación de Cultura Islámica, December 17. Отримано 3 http://twistislamophobia.org/en/2018/12/17/another-

islamophobic-conspiracy-theory-the-islamization-of-theyellow-vests/

Meleagrou-Hitchens A. \& Hans B. (2013). A NeoNationalist Network: The English Defense League and Europe's Counter-Jihad Movement. International Centre for the Study of Radicalisation and Political Violence, March 14. Отримано 3 https://icsr.info/wpcontent/uploads/2013/03/ICSR-Report-A-Neo-NationalistNetwork-The-English-Defence-League-and-

Europe \%E2\%80\%99s-Counter-Jihad-Movement.pdf

Understanding conspiracy theory. European Parliamentary Research Service. (2016). Отримано 3 http://www.europarl.europa.eu/ RegData/etudes/ATAG/2016/ 580917/EPRS_ATA(2016)580917_EN.pdf

Uscinski, J. E. (2017). The Study of Conspiracy Theories. Argumenta. Отримано 3 https://www.argumenta.org/wpcontent/uploads/2017/10/Argumenta-Joseph-Uscinski-TheStudy-of-Conspiracy-Theories.pdf

\section{REFERENCES}

Brotherton, R., French, C., Pickering, D. (2013). Measuring belief in conspiracy theories: the generic conspiracist beliefs scale. PubMed, May 21. Retrieved from https://www.ncbi.nlm.nih.gov/pubmed/ 23734136

Hafez, F. (2018). Another Islamophobic conspiracy theory: The Islamization of the 'yellow vests'. Fundación de Cultura Islámica, December $17^{\text {th }}$. Retrieved from http://twistislamophobia.org/en/2018/12/17/another-islamophobicconspiracy-theory-the-islamization-of-the-yellow-vests/

Meleagrou-Hitchens, A., Hans B. (2013). A NeoNationalist Network: The English Defense League and Europe's Counter-Jihad Movement. International Centre for the Study of Radicalisation and Political Violence, March $14^{\text {th }}$. Retrieved from https://icsr.info/wpcontent/uploads/2013/03/ICSR-Report-A-Neo-Nationalist-

Network-The-English-Defence-League-and-

Europe\%E2\%80\%99s-Counter-Jihad-Movement.pdf

Nemyrovskyi, B. (2017). Is the «Islamization» of Europe real or the Three immigration scenarios for the EU. [in Ukrainian]. 24 Channel, December $1^{\text {st }}$. Retrieved from https://24tv.ua/buti_chi_ne_buti_islamizatsiyi_yevropi_abo_tri _immigratsiyni_stsenariyi_dlya_yes_n896354

Tilley, J. (2019). Why so many people believe in conspiracy theories. [In Russian]. BBC News (Ukraine), February $2^{\text {nd }}$. Retrieved from https://www.bbc.com/ukrainian/ features-russian-47224739

Understanding conspiracy theory. (2016). European Parliamentary Research Service. Retrieved from http://www.europarl.europa.eu/RegData/etudes/ATAG/ 2016/580917/EPRS_ATA(2016)580917_EN.pdf

Uscinski, J. E. (2017). The Study of Conspiracy Theories. Argumenta. Отримано 3 https://www.argumenta.org/wpcontent/uploads/2017/10/Argumenta-Joseph-Uscinski-TheStudy-of-Conspiracy-Theories.pdf 